\title{
40. GEOLOGIC HISTORY AND ORIGIN OF SAO PAULO PLATEAU (SOUTHEASTERN BRAZILIAN MARGIN), COMPARISON WITH THE ANGOLAN MARGIN, AND THE EARLY EVOLUTION OF THE NORTHERN SOUTH ATLANTIC
}

\author{
Naresh Kumar and L.A.P. Gambôa, ${ }^{1}$ Lamont-Doherty Geological Observatory \\ of Columbia University, Palisades, New York \\ B.C. Schreiber, Queens College, City University of New York, Flushing, New York \\ and \\ J. Mascle, Université Pierre et Marie Curie, Centre de Geodynamique sous Marine, \\ 06230 Villefranche - sur mer, France
}

\begin{abstract}
The São Paulo Plateau is a prominent marginal plateau in the southern Brazilian margin. It is underlain by oceanic crust and is bounded to the north and south by fracture zones. Seismic profiles and drilling data from Site 356 (located on its southeastern corner) indicate that the region occupied by the plateau has acted as a depocenter and has evolved as a marginal plateau since the Aptian time. The oceanographic conditions and depositional environments prevailing over the plateau during its early evolution were almost identical to those suggested in the Angolan margin by the drilling data at Site 364 (DSDP).

Reconstruction of the evolution of São Paulo Plateau and comparison between the drilled geologic sequences on the opposing margins suggest the following history for the northern South Atlantic. Coarse terrigenous sediments were deposited in coastal basins at both the margins following the opening of the South Atlantic in the Neocomian. By Aptian time, a linear narrow basin, with barriers to the south and north, was created. The Walvis and São Paulo ridges formed the southern barrier whereas the equatorial fracture zones appear to have formed the northern barrier. An evaporite layer, which continuously extended from Brazil to Africa, was deposited in the basin during middle to late Aptian. At the end of Aptian, the evaporite deposition ceased and the evaporite layer was split along the present-day seaward boundaries of the diapir zones located in the Brazilian and West African margins. As evidenced by limestones with sapropels of late Aptian to early Albian age at Site 364, stagnant conditions prevailed in the basin at the end of evaporite deposition. Open-marine limestones, drilled at Site 356 as well as at Site 364 , suggest that the basin became well oxygenated by the Albian time. Another basin-wide period of stagnation is suggested by black shales and mudstones of Turonian-Coniacian age at Site 356 and of Turonian-Santonian age at Site 364. The terrigenous nature of these sediments suggests supply from the adjacent shelves in the two margins. The waters of the South Atlantic have remained well circulated and oxygenated since then.
\end{abstract}

\section{INTRODUCTION}

The São Paulo Plateau is located off the southeastern Brazilian margin between the latitudes $23^{\circ} \mathrm{S}$ and $28^{\circ} \mathrm{S}$ (Figure 1). Geophysical work in the area carried out in the 1960s revealed the presence of large diapiric structures which were interpreted as salt diapirs (Baccar, 1970; Butler, 1970; Leyden et al., 1971). Although this

\footnotetext{
'Also at Department of Geological Sciences, Columbia University, New York, New York.
}

geophysical work provided a general frame work for the seismic structure of the area, its origin, history, and evolution remained largley unknown. Subsequently, detailed seismic, gravity, and magnetic surveys along with coring and dredging were carried out on the plateau in 1972, 1973, and 1974 by the research vessels of Lamont-Doherty Geological Observatory (L-DGO). Concurrently, during the Geobresil cruise of 1973, R/V Jean Charcot of Centre National pour l'Exploitation des Oceans (CNEXO), France, collected additional seismic, gravity, and magnetic data from the plateau 


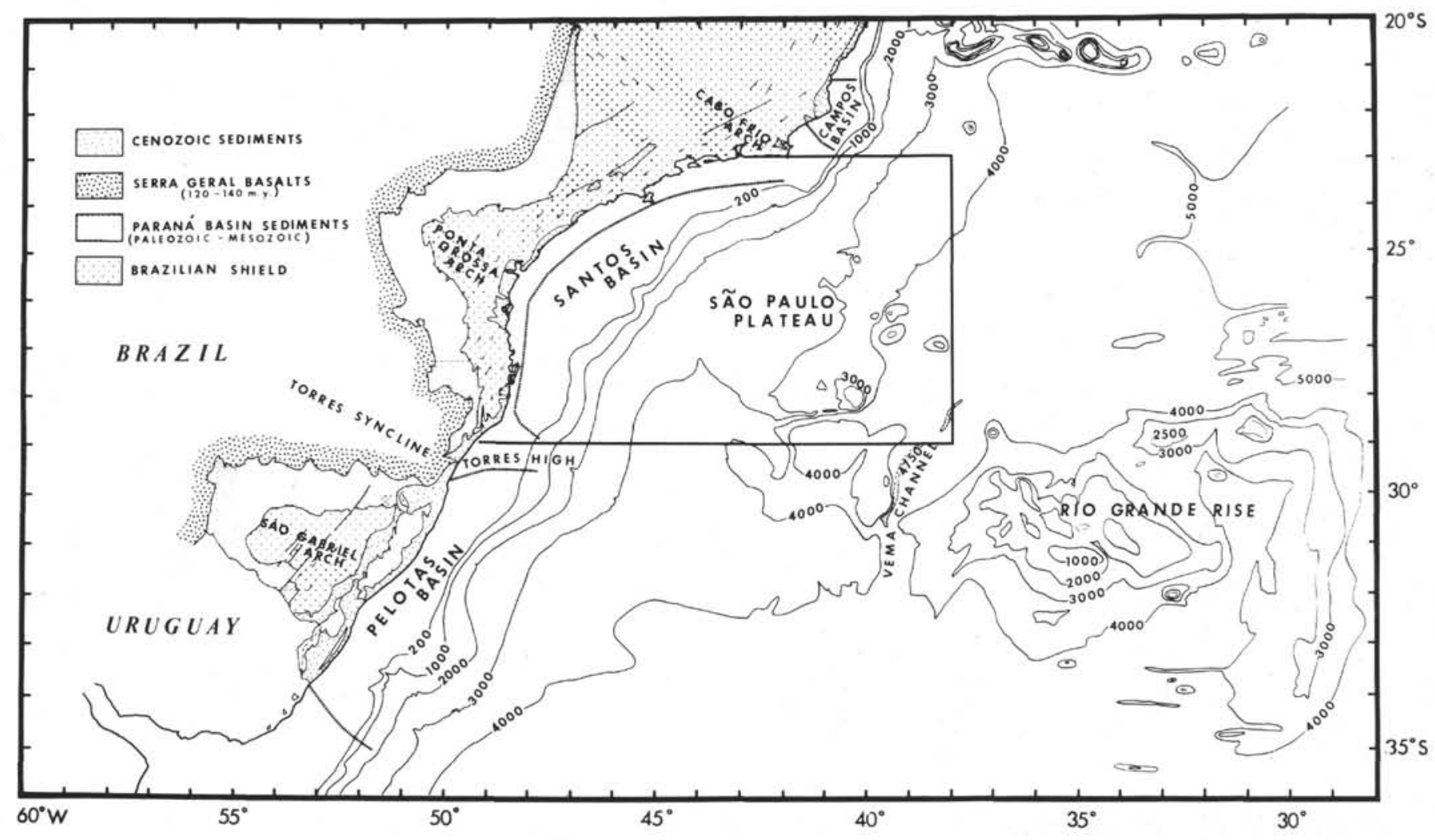

Figure 1. Regional setting of São Paulo Plateau in the southwest Atlantic. Land geology from the Geologic Map of Brazil (1971). Simplified bathymetry in corrected meters from Connary and Moody (unpublished L-DGO bathymetric map).

The outlined area is shown in Figures 2 and 3.

(Mascle and Renard, 1976). Although all these data provided a comprehensive geophysical coverage of the plateau, the seismic data lacked stratigraphic control. Hence, D/V Glomar Challenger drilled Site 356 on the southeastern corner of the plateau in November 1974. Through an analysis of geologic and geophysical data in a $1^{\circ}$ square area, Gamboa and Kumar (this volume) describe the local setting of Site 356.

A discussion of the regional geology, structure, and early depositional environments of the São Paulo Plateau is presented in this paper. In order to reconstruct the early evolution of the northern part of the South Atlantic, we have attempted to compare the Brazilian and West African margins. However, because we have not studied the Angolan margin in the same manner as the São Paulo Plateau, this comparison is rather limited. We have primarily compared the drilling data from Site 356 with the data from Site 364 (lat $11^{\circ} 34^{\prime} \mathrm{S}$, long $11^{\circ} 58^{\prime} \mathrm{E}$ ) in the Angolan margin (Bolli, Ryan, et al., 1975). Seismic data from the vicinity of Site 364 are also compared with the seismic data from São Paulo Plateau

\section{REGIONAL SETTING AND MORPHOLOGY OF SAO PAULO PLATEAU}

The main surface of the plateau lies in water depths of 2000 to 3500 meters off the southeastern margin of Brazil (Figure 2). It is approximately $600 \mathrm{~km}$ at its widest and is located seaward of a wide shelf which is underlain by thick sediments deposited in the Santos
Basin-an offshore coastal basin of Mesozoic age (Figure 1). A narrow strip of Cenozoic sediments fringes the coastline. Precambrian rocks separate the inland Paleozoic Paraná basin from the offshore Santos Basin. These Precambrian rocks form the Ponta Grossa Arch, which extends under the Paraná basin sediments (Geological Map of Brazil, 1971, Figure 1).

The diapiric structures, initially described only from the plateau, actually form an extensive zone along the Brazilian continental margin extending from the southern edge of the São Paulo Plateau to latitude $10^{\circ} \mathrm{S}$ (Leyden and Nunes, 1972). A similar diapir belt has been mapped off the African margin by Leyden et al. (1972) and Pautot et al. (1973). If the seaward edges of these two diapir zones on both sides of the Atlantic are brought together, they fit into each other and form one continuous zone of salt deposition in the South Atlantic (Leyden and Nunes, 1972; Leyden et al., 1976).

An east-west trending ridge (the São Paulo ridge) marks the southern boundary of the plateau (Figure 2). The southern flank of this ridge has a steep relief exceeding 2000 meters. A U-shaped trough with a flat bottom parallels the southern flank of the São Paulo ridge. The trough reaches a maximum depth of 500 meters below the adjacent sea floor to the south. The 3500 -meter isobath, along which minor escarpments are present, marks the eastern boundary of the plateau. The northern boundary of the plateau is not marked by any topographic feature, but is inferred to be located where the Brazilian coastline and the 200- and 500- 


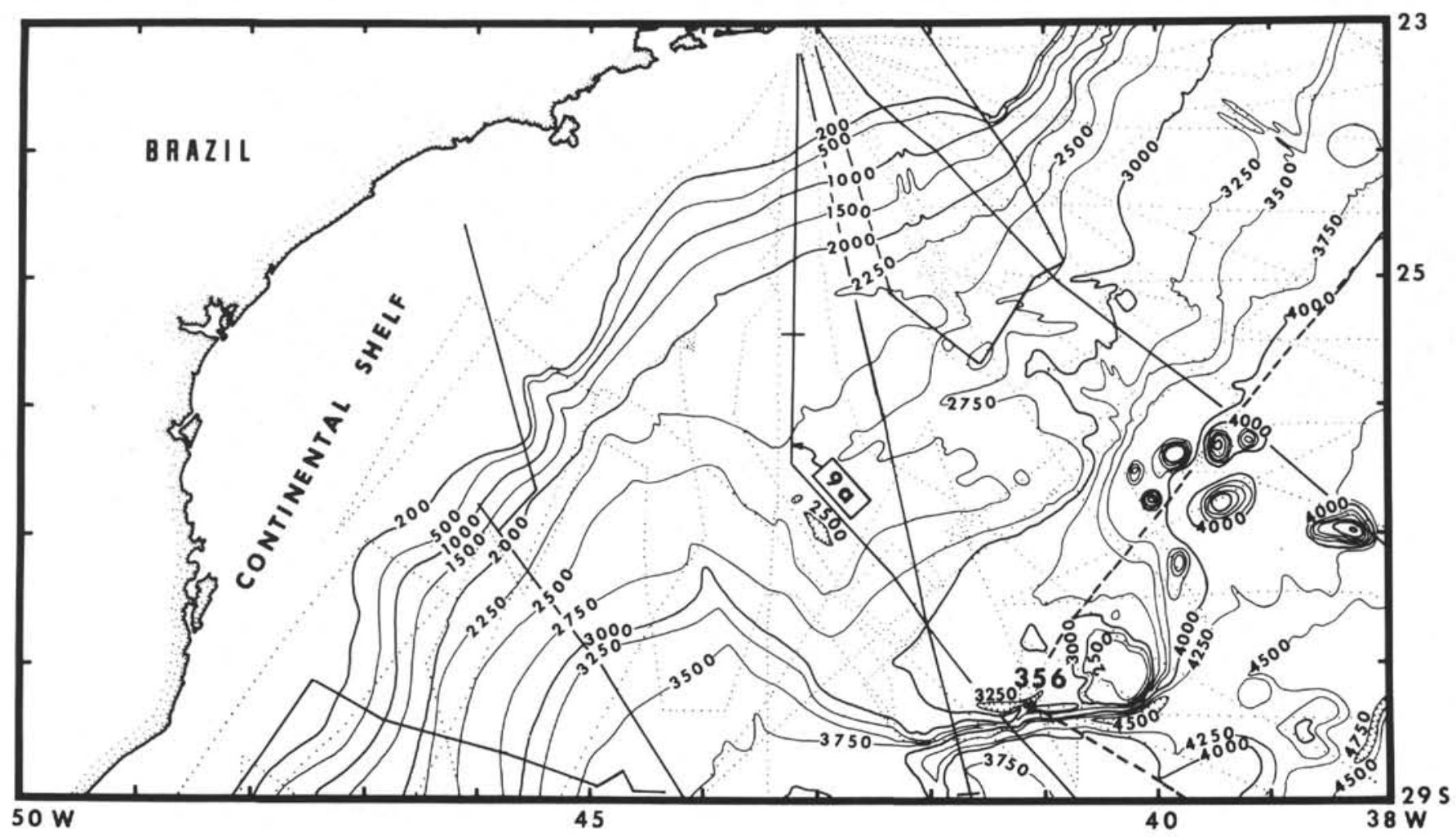

Figure 2. Bathymetry in corrected meters of the São Paulo Plateau and environs (from Connary and Moody, unpublished L$D G O$ bathymetric map). Dotted lines show the various tracks made by $R / V$ Vema and $R / V$ Conrad of $L-D G O$ in the area. Dashed line marks the track made by the $D / V$ Glomar Challenger during Leg 39. Continuous lines represent $R / V$ Jean Charcot profiles in the area. Site 356 shown by a star. Location of the profile shown as Figure $9 a$ is also marked.

meter isobaths abruptly turn east-west (Figures 1 and 2). The 200-meter isobath approximates the western boundary of the plateau.

The surface of the plateau is irregular and has been created mainly by intruding diapiric structures that have disturbed the overlying sediments (Figure 2). Basement outcrops in the southern part of the plateau contribute to the rough morphology. The outer parts of the plateau are marked by piercement diapirs lying at relatively shallow subsurface depths; the inner parts of the plateau contain diapirs that are covered by thicker sediments (Mascle and Renard, 1976; Kumar and Gamboa, in preparation).

\section{STRUCTURE OF SAO PAULO PLATEAU}

Seismic-refraction measurements have revealed that underlying the sedimentary layers of the plateau (1 to 2 $\mathrm{km}$ thick with a velocity of 1.8 to $1.9 \mathrm{~km} / \mathrm{sec}$; and the evaporite layer, 2 to $3 \mathrm{~km}$ thick with a velocity of 3.8 to $4.9 \mathrm{~km} / \mathrm{sec}$ ) are layers with velocity ranges of 5.1 to 5.6 $\mathrm{km} / \mathrm{sec}$ ( 2 to $4 \mathrm{~km}$ thick) and 6.4 to $6.8 \mathrm{~km} / \mathrm{sec}$ (Leyden et al., 1971). These authors correlated the latter two layers as layers 2 and 3, respectively, suggesting that the crust underlying the plateau is oceanic. The fit of South America and Africa at the 500 fathom contour proposed by Bullard et al. (1965) implies that the crust under the plateau was created since the opening of the South Atlantic and hence should be oceanic. The presence of linear magnetic anomalies on the plateau, which have not yet been mapped in enough detail to be correlated with the sea-floor spreading anomalies in the South Atlantic, is consistent with the conclusion that oceanic crust underlies the plateau (Cande, personal communication, 1975). Although Mascle and Renard (1976) accept the idea that oceanic crust forms the basement for the São Paulo Plateau, they suggest that a clastic sequence exists between the evaporites and the igneous crust. The evidence for a pre-evaporite clastic layer under the plateau is not very clear. This question is significant and deserves further work.

Although the drilling at Site 356 failed to reach igneous basement, basalt fragments in the drilled sedimentary section, large magnetic anomalies associated with the São Paulo ridge (Cande and Rabinowitz, in preparation), and the L-DGO dredge hauls from the southern flank of the ridge (dredges 9, 10, RC16-10, 1973) all indicate that this ridge is composed of mafic igneous rocks. In addition to the São Paulo ridge, two buried troughs and two buried highs occur at the southern edge of the São Paulo Plateau (Figure 3). These troughs and highs are continuous in an east-west direction and can be traced from track to track from $42^{\circ} \mathrm{W}$ to $38^{\circ} \mathrm{W}$ (Figure 3 ) and even farther eastward to $29^{\circ} \mathrm{W}$ longitude. Their continuity in the oceanic basement suggests that they are expressions of an east-west trending fracture zone. Various authors have suggested that such continuous ridges and troughs in the oceanic basement define a fracture zone in the equatorial Atlan- 


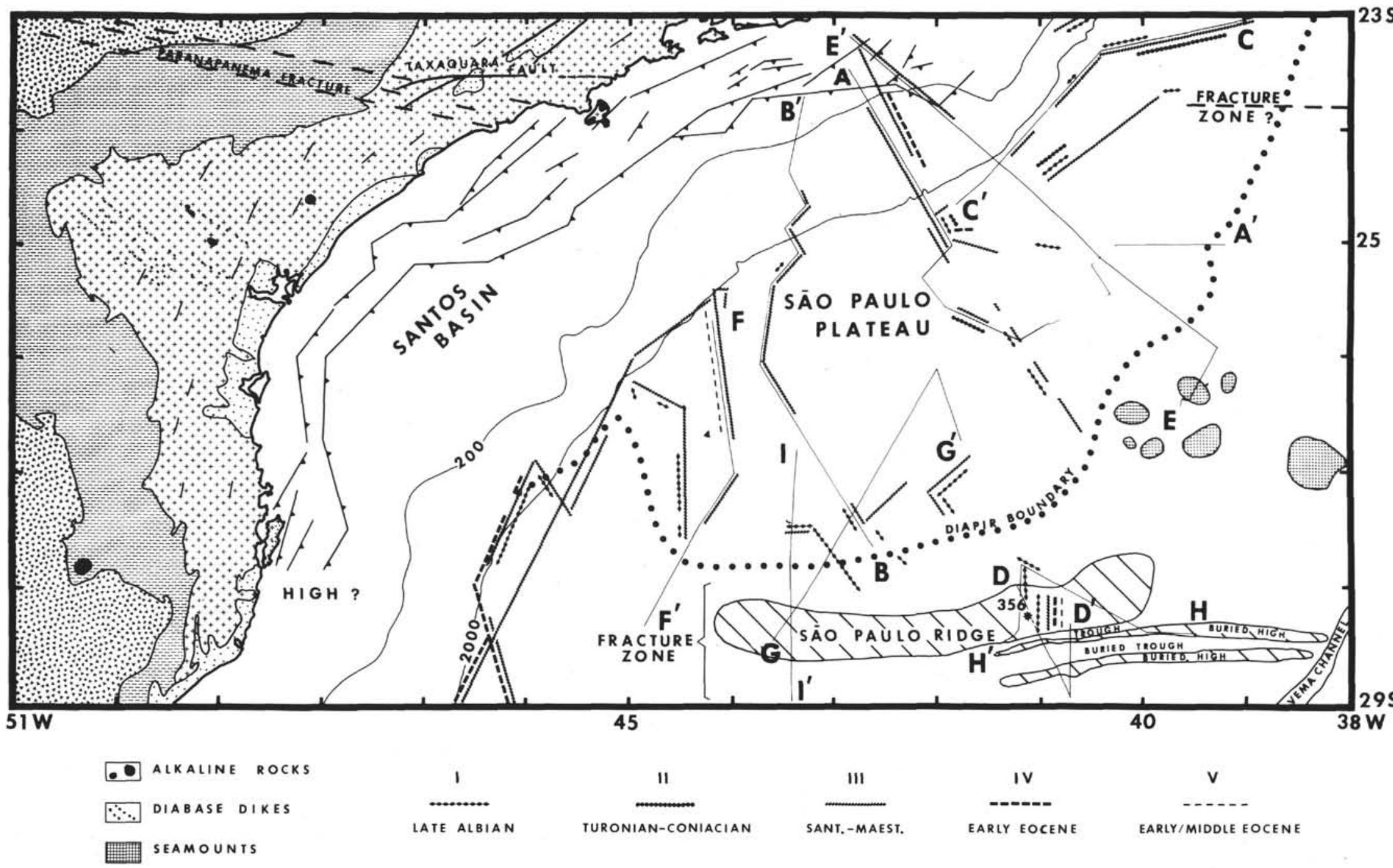

Figure 3. Simplified structure map of the São Paulo Plateau area. Reflectors I through $V$, discussed in the text, have been mapped along the available tracks. Each reflector is marked along that segment of a track where that reflector was visible on the profiler record. Thin straight lines marked as $A A^{\prime}, B B^{\prime}$, etc. refer to the tracks along which profiler records and tracings have been shown in Figures 4 and 5. Shelf structure from Petrobrás (unpublished data). Land geology from the Geological Map of Brazil (1971). Symbols for land geology same as in Figure 1. Locations of Paranapanema fracture and Taxaquara fault from Fulfaro (1975) and Rideg (1974), respectively. Normal faults on the shelf marked as straight line segments with solid triangles on the downthrown side (from Petrobras unpublished data). Further details on the figure and in text. 
tic (Gorini and Bryan, 1976; Delteil et al., 1974). Furthermore, east of $35^{\circ} \mathrm{W}$ longitude, magnetic anomalies have been offset across the trend of these ridges and troughs (Ladd, 1974). Fodor et al., (this volume) and Mascle and Renard (1976) also support the suggestion that the São Paulo ridge is located along a fracture zone.

The São Paulo ridge continues westward toward the Brazilian margin. Its surface expression becomes less pronounced west of $42^{\circ} \mathrm{W}$, and it is buried by sediments west of $43^{\circ} \mathrm{W}$ (Profile I I', Figure 4, location on Figure $3)$. Our profiler records do not show any expression of the São Paulo ridge west of $44^{\circ} \mathrm{W}$ longitude, presumably because it is buried too deeply. On land, however, the southern boundary of the Precambrian Ponta Grossa Arch appears to lie along the trend of the São Paulo ridge (Figure 3) and a structural high, marking the southern boundary of the Santos Basin, appears to extend offshore from the city of Florianópolis at $28^{\circ} \mathrm{S}$ latitude (Asmus, 1975 and personal communication, 1975). Alkaline rocks are exposed along this trend more than $200 \mathrm{~km}$ inland. We therefore propose that the southern boundary of the São Paulo Plateau is marked by a fracture zone which may also form the southern boundary of the Santos Basin and may connect with the southern boundary of the Ponta Grossa Arch on land. The São Paulo ridge forms the northern boundary of this fracture zone.

A fracture zone also seems to mark the northern structural boundary of the plateau. This boundary appears to be located where the diapir zone begins to narrow slightly north of $24^{\circ} \mathrm{S}$. The presence of a fracture zone at the northern boundary of the plateau is suggested by the following: (1) magnetic anomalies are offset at this latitude eastward of the area covered by Figure 3 (Ladd, 1974), (2) immediately north of $24^{\circ} \mathrm{S}$ the 200- and 500-meter isobaths turn sharply in an eastwest direction, and (3) an east-west trending fault on the shelf at the same latitude marks the northern boundary of the Santos Basin. Francheteau and Le Pichon (1972) also have suggested the presence of a fracture zone at this latitude (their " $42.5^{\circ}$ fracture zone") and Rideg (1974) connects it with the east-west trending Taxaquara fault on land (Figure 3); the latter fault appears to intersect the Brazilian coastline at $23^{\circ} 30^{\prime} \mathrm{S}$ (Rideg, 1974, Figure 3). Another east-west fault system, termed the "Paranapanema fracture," intersects the coastline at $24^{\circ} \mathrm{S}$ (Fulfaro, 1975). At this time we are unable to say whether the proposed fracture zone north of $24^{\circ} \mathrm{S}$ latitude connects on land with the Taxaquara fault or with the Paranapanema fracture or with both. Marsh (1973) has proposed a fracture zone in this general region on the basis of the outcrops of alkaline rocks on land. Thus, a single fracture zone appears to form the northern boundary of the São Paulo Plateau as well as of the Santos Basin. On land, this fracture zone appears to connect with the east-west structural lineation present in the area. As shown by Mascle and Renard (1976), the two fracture zones proposed here trend more or less in the direction predicted by the early pole proposed by Mascle and Sibuet (1974) for the opening of the South Atlantic. The direction of these fracture zones also does not differ significantly from that predicted by the early pole of opening of Francheteau and Le Pichon (1972). On the basis of bathymetric offsets, Mascle and Renard (1976) suggest that several other fracture zones may occur between those described above but other indications of major fracture zones passing through the São Paulo Plateau are not seen.

From the northern limit of the São Paulo Plateau to $26^{\circ} \mathrm{S}$ latitude, the eastern boundary of the plateau is marked by the seaward edge of the diapir zone, which is expressed as a minor escarpment in the seismic profiles. However, between $26^{\circ} \mathrm{S}$ and $27^{\circ} \mathrm{S}$ latitudes, the seaward edge of the diapir zone does not form a morphologic scarp. Because sediments coming from the west appear to have ponded against the seamounts present in this area (Figure 4, Profile EE', location on Figure 3), we believe that south of $26^{\circ} \mathrm{S}$ latitude the eastern boundary of the plateau lies along a line connecting the eastern edge of the diapir zone with the eastern end of the São Paulo ridge. The main surface of the plateau intersects the continental slope at depths varying between 2000 and 2500 meters, but our profiles do not show any structure separating the Santos Basin from the São Paulo Plateau. In fact, as we show later, the stratigraphy of the two areas demonstrates that they have remained structurally connected at least since late Cretaceous.

\section{STRATIGRAPHY OF SAO PAULO PLATEAU}

The stratigraphy of São Paulo Plateau is derived from the correlation of seismic reflectors drilled at Site 356 (Perch-Nielsen, Supko, et al., this volume) with the reflectors mapped throughout the plateau. The lithology and ages of various stratigraphic units at Site 356 are extrapolated to the entire plateau. The drill site is located on the sediment-covered part of the northern flank of São Paulo ridge (Figure 3). Large diapirs are absent in this region; either the salt layer is too thin to form diapirs or a different sedimentary facies, equivalent to the salt in age, exists at this location. The drilling was expected to sample the entire sedimentary column including the evaporite facies and the igneous basement. Unfortunately, it had to be discontinued at a depth of 741 meters in late Albian limestones; neither the evaporites nor the basement were drilled.

Figure 3 shows that five stratigraphic reflectors have been identified and mapped on the plateau; four of these reflectors were drilled and dated at Site 356. In Figure 3 a correlatable reflector is shown along that part of a track where it was visible on the seismicprofiler record. Some of the seismic profiles used for mapping the relfectors, and the tracings of these records, are shown in Figures 4 and 5, respectively.

The deepest reflector drilled and dated at Site 356 (Perch-Nielsen, Supko, et al., this volume) occurs at a subbottom depth of $0.75 \mathrm{sec}$ and marks the top of late Albian marly dolomitic limestones (Unit 7 at Site 356, Perch-Nielsen, Supko, et al., this volume); they were the oldest sediments drilled at Site 356. The next overlying reflector occurs at a subbottom depth of $0.5 \mathrm{sec}$ and marks the top of Santonian to mid-Maestrichtian marly 



Figure 4. Examples of seismic-profiler records from the São Paulo Plateau area. Locations of these profiles on Figure 3. Vertical exaggeration is between 1:12 and 1:25. Tracings for these sections shown in Figure 5. 

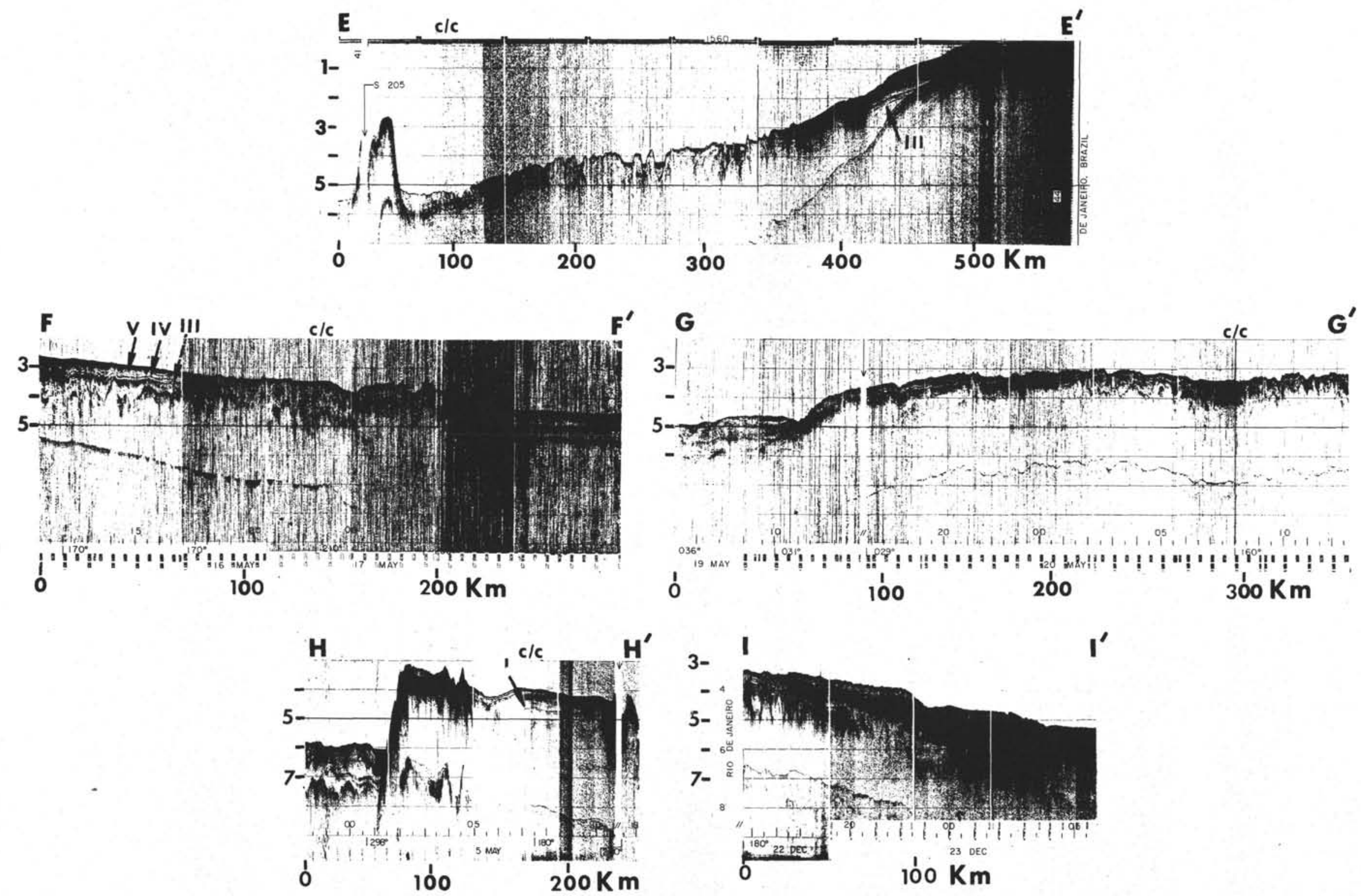

Figure 4. (Continued). 



Figure 5. Simplified tracings from the seismic-profiler records shown in Figure 4. Diapiric structures are seen on almost all the profiles except in profiles DD' and $H H^{\prime}$. Numbers I through $V$ refer to the five major reflectors discussed in the text and mapped in Figure 3. Black areas are presumed basement highs. Vertical exaggeration is between 1:12 and 1:25. 

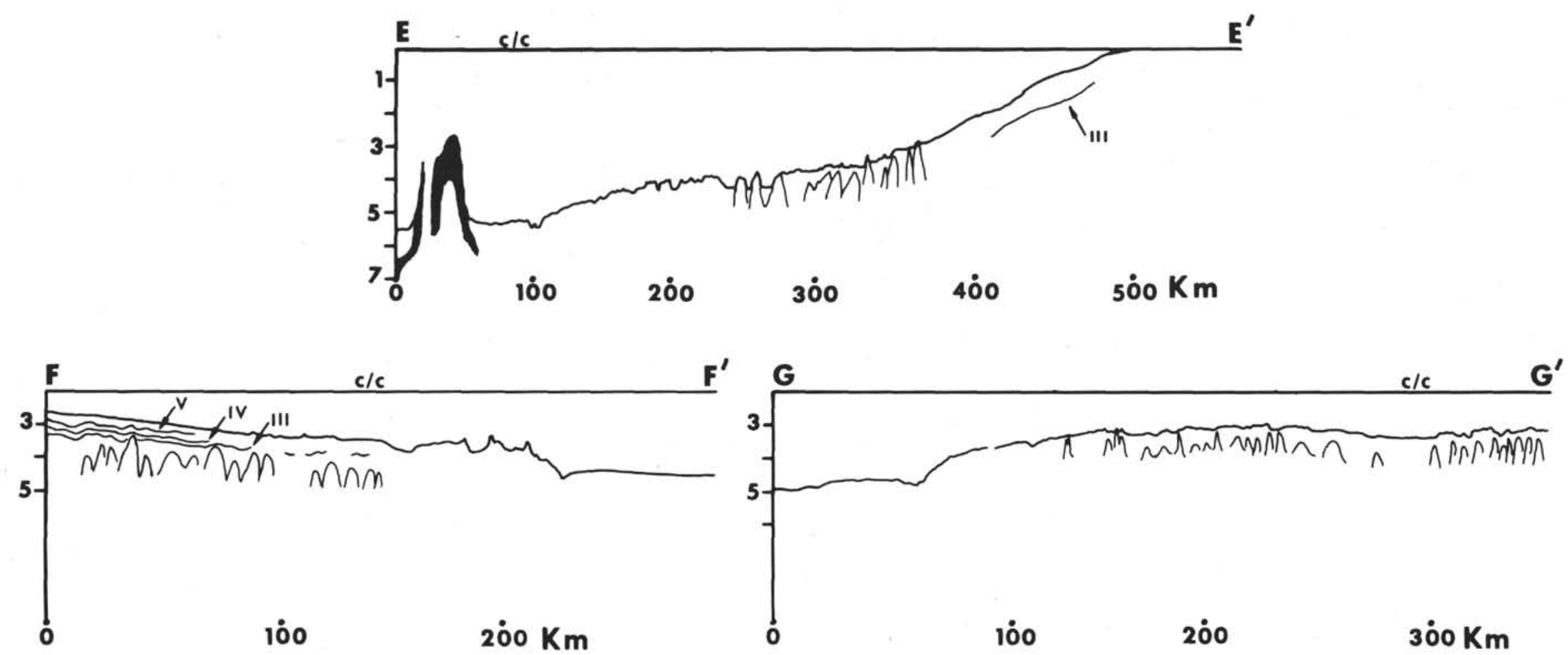

Figure 5. (Continued).

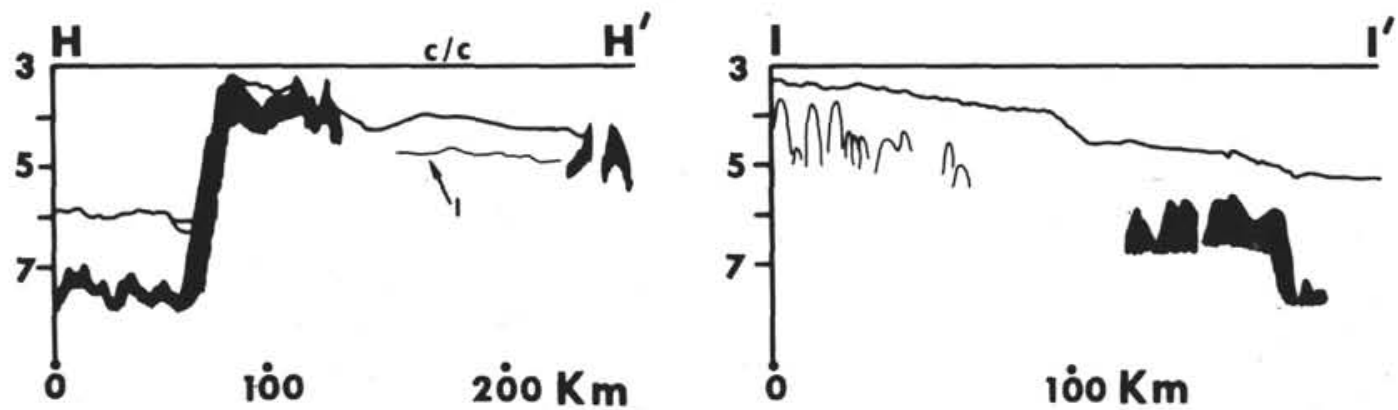


chalks (Unit 5 at Site 356). Two younger reflectors occur at subbottom depths of 0.28 and $0.12 \mathrm{sec}$, respectively, and mark the tops of early Eocene silicified chalk and early Eocene to middle Eocene siliceous-calcareous oozes (top of Units 3 and 2 at Site 356, respectively).

Besides these four reflectors, a fifth reflector, which was not seen at Site 356, occurs on some L-DGO seismic profiles (profiles $\mathrm{AA}^{\prime}, \mathrm{CC}^{\prime}$, Figures 4 and 5). This reflector occurs at approximately $0.2 \mathrm{sec}$ above the late Albian reflector. Because it occurs mainly at the base of the slope, the reflector might mark the top of a terrigenous layer overlying the late Albian limestone. At Site 356, a terrigenous layer (Unit 6), composed of clay-pebble conglomerates and dark shales overlies the limestone. If our correlation is correct, the absence of this reflector at Site 356 can be explained by the fact that Unit 6 at the drill site is only 43 meters thick.

The five reflectors mentioned above are designated here as Reflectors I (top of Unit 7, late Albian limestone), II (top of Unit 6, Turonian-Coniacian mudstone), III (Unit 5, top of Santonian-Maestrichtian marly chalk), IV (Unit 3, top of early Eocene silicified chalk), and V (Unit 2, top of early to middle Eocene siliceous calcareous ooze) (Figure 6). The diapiric structures which form the upper surface of the evaporitic sequence underlie these refflectors throughout the plateau (Figures 3-5).

\section{SEDIMENTATION HISTORY AND DEPOSITIONAL ENVIRONMENTS OF THE SAO PAULO PLATEAU}

Petrographic and geochemical data provide supplementary information to reconstruct the depositional environments during the deposition of Units 7 and 6 at Site 356. Detailed descriptions and environmental interpretations of these units are presented in the Chapter on Site 356 in this volume.

The marly limestone of Unit 7 at Site 356 is primarily composed of calcareous biogenic material, dolomite, and clay minerals. The matrix is a very fine micritic lutite. The individual foraminifer are all generally small and are in-filled with sparry calcite. The foraminiferal assemblage suggests a water depth of 600 to 1000 meters in the Albian when these limestones were deposited indicating a general subsidence of approximately $3 \mathrm{~km}$ of the northern flank of São Paulo ridge, where Site 356 is located (see Site Report chapter, Site 356 , this volume). Erosion by bottom currents is indicated because the foraminifer in the matrix appear to have been winnowed and are sometimes concentrated in very thin laminae.

Into such a general setting, material represented by individual laminae ranging from $1 \mathrm{~mm}$ to $1 \mathrm{~cm}$ in thickness was introduced from a very different environment. The laminae display small-scale load casts, flame structures, and are occasionally graded (Figure 7A). Some of these laminae are cross-laminated (Figure 7B), whereas some others are ungraded (Figure 7C). These laminae are composed of shallow-water carbonates, oöids (Figure 7D), bryozoan, pelecypod, and rudistid fragments, shallow-water benthic foraminifers, and an important volcanic component that consists of basalt pebbles coated with algal-carbonate overgrowths (Figure 7E). The composition, texture and sedimentary structures of these laminae indicate that they were emplaced by gravity flows and that the source area was volcanically active and was apparently either in very shallow water or subaerially exposed. An obvious source for the volcanic material is the São Paulo ridge which, as suggested by approximately $3 \mathrm{~km}$ of subsidence of its northern flank, was probably much shallower in the Albian than today. Another indication that the São Paulo ridge was at, or above sea level during early, and parts of late Cretaceous is provided by the alkaline composition of a basalt pebble, presumably derived from the ridge, and occurring in Unit 5 at Site 356. The composition of this pebble is akin to the petrology of basalts commonly forming volcanic islands (Fodor et al., this volume). If the ridge supplied the volcanic material when it was at or near the sea level, it could also supply the shallow-water calcareous biogenic material present in the laminae of Unit 7. Thus, although most of the material contained in the laminae could have come from the Brazilian margin, we think that the São Paulo ridge is the more likely source for the displaced material in Unit 7 .

Following the deposition of marly limestones of Unit 7 , mudstones, conglomerates (Figure 8A, B), and black shales (Figure 8C) of Unit 6 were deposited at Site 356. Unit 6 contains conglomerate to claystone sequences in its upper parts which are separated by light gray calcareous mudstone beds (see Site Report chapter, Site 356 , this volume). Toward the base of the unit, black shale intervals alternate with calcareous mudstones.

The bottom conditions were anaerobic at the time black shales of Unit 6 were deposited. This is supported by the presence of pyrite, and high content of organic carbon (up to $12.61 \%$ ) present in the sediments of Unit 6 . Although the $\delta \mathrm{C}^{13}$ PDB of the whole sample represents open-marine conditions (values ranging from -27.4 to 23.6), the $\delta \mathrm{C}^{13} \mathrm{PDB}$ of the aromatic fraction from the LIPID shows values of -30.6 and -32.4 , indicating brackish and fresh-water origin of the organic material (Foresman, in press). Hence, the sediments of Unit 6 at Site 356 represent stagnant conditions at the bottom into which fine terrigenous sediment was introduced from outside. This terrigenous material is different from the shallow-water calcareous material present in Unit 7. Furthermore, if Reflector II marks the top of Unit 6, a shoreward thickening of this unit is suggested by the profiler records. Hence, we suggest that the terrigenous material in Unit 6 was derived from the Brazilian shelf and not from the São Paulo ridge. However, the basalt fragments (Figure 8D) in this unit represent a secondary input from the ridge. The conglomerate-to-claystone sequences in the upper part of the unit represent local slumping because if they had been derived from the shelf, the conglomerates would not be almost exclusively composed of clay pebbles (identical in composition to the underlying shales and mudstones), but would also contain other fragments derived from the continent. The environment at Site 356 became well oxygenated after the deposition of Unit 6 and has remained so since then (Perch-Nielsen, Supko, et al., this volume). 




Figure 6. Correlation of São Paulo reflectors I through V (Figures 3, 4, 5) with the geology of the Santos Basin (from Ponte and Asmus, 1976). The reflectors appear to be synchronous throughout the plateau and mark important events in the history of the margin. Note that the geologic sections under the Santos Basin and under Site 356 have been drawn against a time scale and not against the depth scale. 
N. KUMAR, L. A. P. GAMBÔA, B. C. SCHREIBER, J. MASCLE
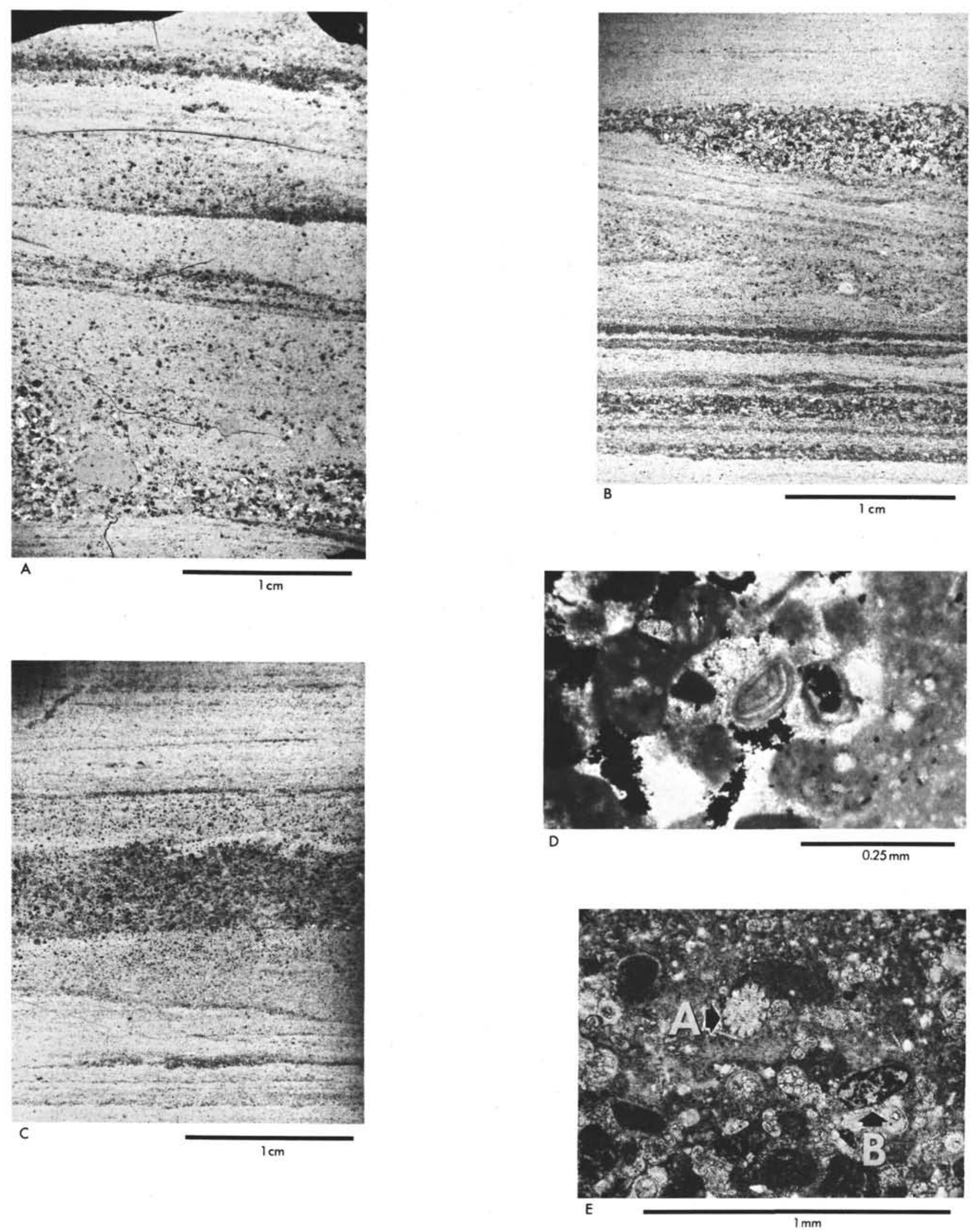

Figure 7. Examples of various structures and textures in Unit 7 at Site 356. (A) Graded bedding in Sample 356-43-1, 119-123 cm. Plane polarized light. (B) Cross laminae in Sample 356-44-5, 20-24 cm. Plane polarized light. (C) Ungraded layer of relatively coarse material in Sample 356-42-3, 95-98 cm. Plane polarized light. (D) An oöid fragment in Sample 356-44-6, 57-61 cm indicating shallow-water high-energy environments in the source area. Sample comes from a coarse layer within the limestone. Cross nicols. (E) Further indicators of shallow-water environments in the source area in Sample 356-44-5, 20-24 cm. Grain marked A is a corallite fragment. Grain marked B is a basalt fragment coated with algal carbonate. The sample comes from a coarse graded layer. Cross nicols. Further details in text. 


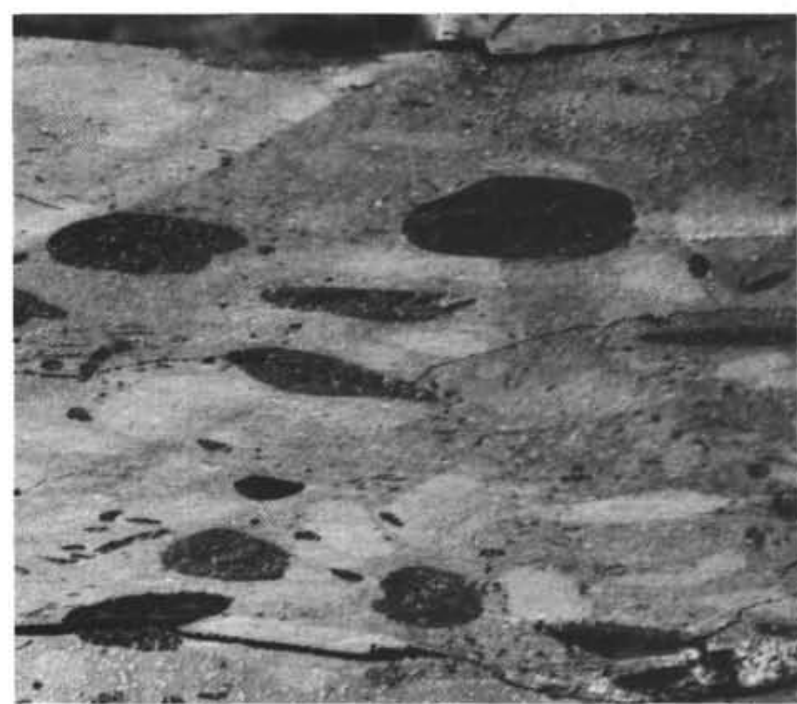

A

$1 \mathrm{~cm}$



B

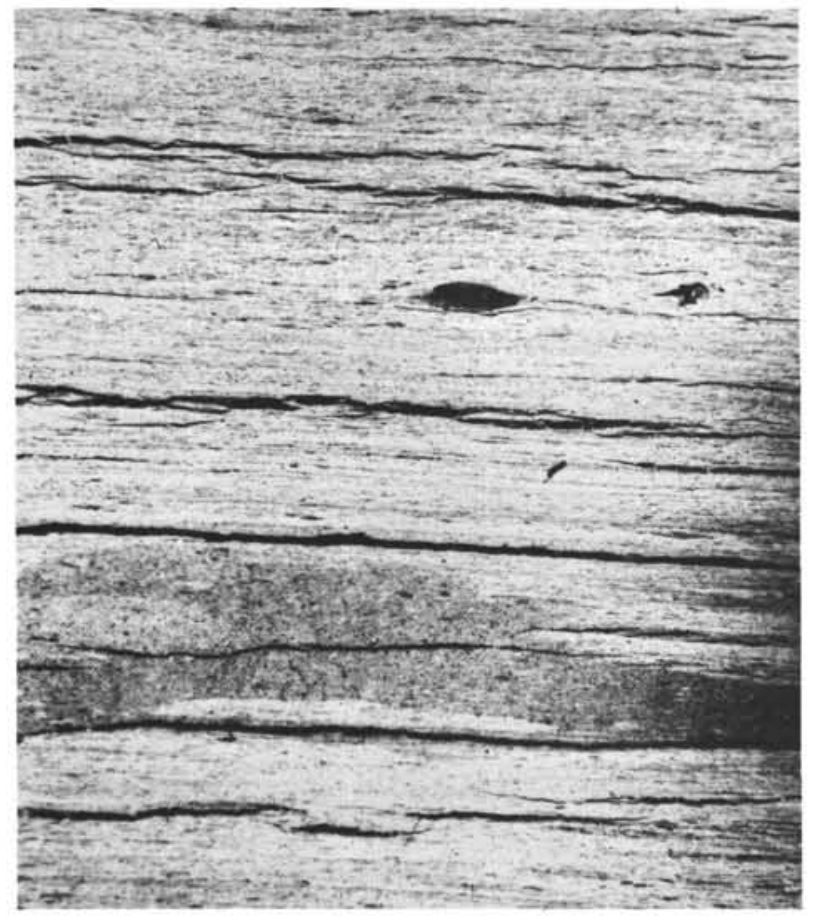

C

$1 \mathrm{~cm}$

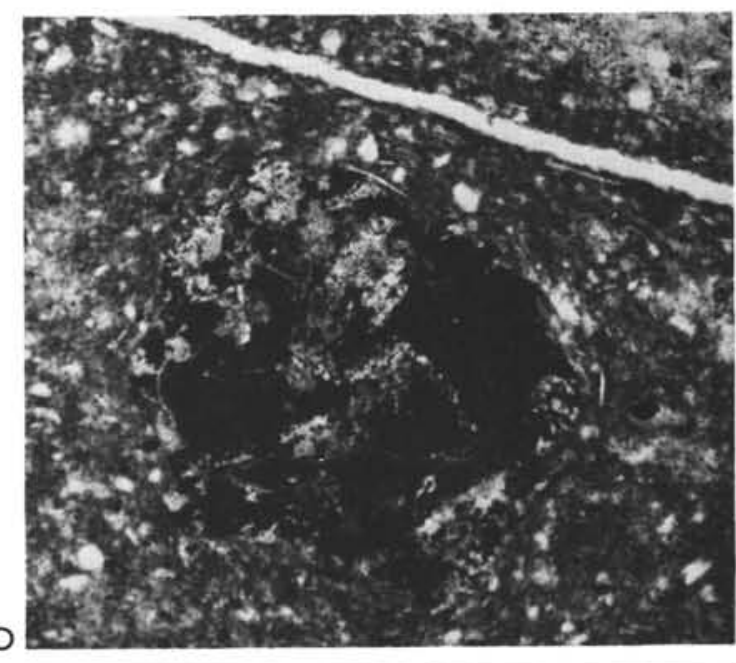

$0.5 \mathrm{~mm}$

Figure 8. Examples of various structures and textures in Unit 6 at Site 356. (A) Clay-pebble conglomerate with light and dark colored clasts. Burrows are evident throughout (Sample 356-39-4, 57-61 cm). (B) Coarse breccia layer in Unit 6 (Sample $356-40-3,62-65 \mathrm{~cm})$. Component clasts include red and green colored altered glass fragments, rounded basalt clasts, carbonate fragments and shale pebbles. (C) Dark shale within Unit 6 (Sample 356-41-4, 47-50 cm). Matrix contains abundant organic material. Calcium carbonate is concentrated in thin light-colored laminae. Plane-polarized light. (D) Altered-basalt fragment within the dark conglomerates of Unit 6 (Sample 356-39-2, 28-32 cm). Presence of these basalt fragment indicate that the São Paulo Ridge was volcanically active during the deposition of Unit 6. Further details in text. 
A comparison between the stratigraphies of the São Paulo Plateau, and the Santos Basin, located under the adjacent shelf (Figure 1), shows that the two have remained interrelated at least since the Aptian time (Kumar and Gamboa, in preparation). A continuous evaporitic layer of Aptian age (Ponte and Asmus, 1976) extends from the basin to the plateau (Figure 6). In the Albian, shallow-platform carbonates were deposited in the basin, while open-marine limestones were deposited on the plateau. Coarse conglomerates were deposited in the basin during the Turonian-Coniacian (Ponte and Asmus, 1976), whereas fine terrigenous material was contemporaneously deposited on the plateau. A major transgression in the Maestrichtian trapped the terrigenous sediments within the plateau and halted terrigenous sedimentation on the plateau (Figure 6). Cenozoic sediments in both areas are open marine. As is also suggested by the seismic data, the sedimentary history suggests that the two regions have remained structurally continuous, at least since the late Cretaceous. The plateau seems to have acted as a depocenter in which the terrigenous input was supplied from the Santos Basin and has evolved as a marginal plateau since the end of Aptian (Kumar and Gamboa, in preparation).

\section{COMPARISON BETWEEN THE BRAZILIAN AND ANGOLAN MARGIN DATA}

The seismic data from the Brazilian and Angolan continental margins and the drilling data from Sites 356 (Brazilian margin) and 364 (Angolan margin) indicate a very similar geologic structure and evolution of the two margins. The lithologies, seismic stratigraphies, and the geochemistry of sediments in the oldest part of both the sequences is also very similar.

Figure 9 shows simplified tracings from seismic profiles made by R/V Jean Charcot on both sides of the Atlantic (Brazilian margin, Figure 9A, location on Figure 2; Angolan margin, Figure 9B, location shown on Figure 10). The two profiles appear almost as mirror images of each other. The black layer in Figure 9 indicates well-developed diapiric structures on both sides of the Atlantic. Hachuring on both profiles indicates inferred oceanic basement underlying the salt layer. We have already discussed the data which favors that oceanic crust underlies the plateau. In the case of African margin, although Beck and Lehner (1974) suggest that continental crust underlies the salt, recent data (Renard and Mascle, 1974; Emery et al., 1975; Bolli, Ryan, et al., 1975) strongly suggest an oceanic crust underlying at least the seaward part of the salt layer.

The equivalent of Reflector I (which lies at $0.75 \mathrm{sec}$ subbottom at Site 356) occurs at a subbottom depth of $0.73 \mathrm{sec}$ under Site 364 and marks the top of bluish-gray to olive-gray limestone and marly limestone at that site. This lithology is very similar to the lithology of Unit 7 at Site 356. The equivalent of Reflector II which marks the top of Unit 6 at Site 356 occurs at $0.62 \mathrm{sec}$ subbottom at Site 364 and marks the top of TuronianSantonian mudstones with sapropels (Bolli, Ryan, et al., in press). This lithology is almost identical to the lithology of Unit 6 at Site 356. The organic-carbon con- tent and the $\delta \mathrm{C}^{13} \mathrm{PDB}$ values on both sides of the margin are also very similar. The immature hydrocarbons present in Unit 6 at Site 356 are almost identical to the equivalent sapropels of similar age at Site 364 (Foresman, in press). Although, the equivalents of Brazilian reflectors III, IV, and V are not apparent on the African side, we shall show later that there are many similarities between the post-Santonian sections on both sides as well.

\section{EVOLUTION OF NORTHERN SOUTH ATLANTIC AND THE OPPOSING MARGINS}

The South Atlantic began to open approximately 127 m.y. ago (Larson and Ladd, 1973). The magneticanomaly pattern (Ladd, 1974) and the location of proposed poles of opening (Le Pichon and Hayes, 1971; Francheteau and Le Pichon, 1972) require the rate of spreading to be higher in the south than in the north. Hence, we can assume that the northern part of South Atlantic (areas to the north of Rio Grande Rise and Walvis Ridge) was opening more slowly than the southern South Atlantic. The Neocomian early opening in the northern South Atlantic was marked by the deposition of thick terrigenous, shallow marine, fluvial, and lacustrine sediments in the coastal basins of the Brazilian as well as of the West-African margin (Brink, 1974; Asmus and Ponte, 1973; Asmus, 1975; Campos et al., 1974; Mascle and Renard, 1976). This stage in the opening of the northern South Atlantic has been referred as the "rift-valley stage" (Asmus, 1975; Ponte and Asmus, 1976).

By the Aptian time the configuration in the northern South Atlantic was such that a continuous barrier was formed by the São Paulo ridge and the Walvis Ridge (Leyden et al., 1976; Leyden and Nunes, 1972). In the equatorial Atlantic, the marginal fracture ridges, located along the trends of major oceanic fractures zones (Mascle, 1975; Gorini and Bryan, 1976) prevented free circulation between the North and South Atlantic. In fact, Reyment and Tait (1972), on the basis of faunal evidence suggest that a marine connection between the North and South Atlantic was probably not established until the lower Turonian time. Thus conditions were favorable for evaporites to form in a linear, narrow, restricted basin with barriers to open circulation present in the south as well as in the north.

The deposition of salt, at least of that part of the salt which is presently lying in the deep part of the basin, took place entirely within the Aptian, most probably within the late Aptian (Bolli, Ryan, et al., 1975). If the salt directly overlies the oceanic basement (Leyden, 1976; Bolli, Ryan, et al., in press), very little or no sediment must have been deposited in the northern South Atlantic between the Neocomian (when South Atlantic presumably began to open) and the Aptian (when the salts were deposited). On the other hand, if a clastic layer underlies the evaporite layer as suggested by Mascle and Renard (1976), these sediments must have been deposited through progradation of thick terrigenous sediments which were deposited in the coastal basins.

The depth of the basin when the salts were depositing remains unknown. However, the drilling data at Site 356 (Perch-Nielsen, Supko, et al., this volume) and at 




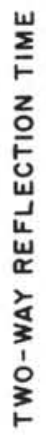



Figure 9. Simplified tracings from the profiles made by $R / V$ Jean Charcot off the Brazilian margin (A) location in Figure 2, and off the Angolan Margin (B) location in Figure 10. Black layer indicates the top part of salt layer with well-developed diapiric structures. Hachures imply the presence of oceanic basement. Projected location of DSDP Sites 356 and 364 shown. The stratigraphy and structure under the salt layer is not well established in either margin (modified from Mascle and Renard, 1976).

Sites 363 and 364 (Angolan basin off the African margin; Bolli, Ryan, et al., in press) indicate that the basin was a few hundred meters deep (approximately 500 to $1000 \mathrm{~m}$ ) at the end of the evaporite deposition. Assuming that the entire salt deposition took place within $3 \mathrm{~m} . \mathrm{y}$. or so, a subsidence of $1 \mathrm{~mm} / \mathrm{yr}$ could accommodate the deposition of $3 \mathrm{~km}$ of salts that are present on both sides of the Atlantic. Although this rate of subsidence is possible, analogy with other salts suggests that the deposition of salts takes place at a rate which is so fast $(10 \mathrm{~mm} / \mathrm{yr}$, Faure, 1976; or more, Schreiber, unpublished data) that the crustal subsidence cannot keep pace with it. Hence, the indirect evidence favors a basin which was approximately $3 \mathrm{~km}$ deep before the salts began to deposit and was almost filled to a depth of less than $1 \mathrm{~km}$ after the salt deposition had ceased (Bolli, Ryan, et al., 1975). Our interpretation also implies that the actual time taken to deposit the evaporite layer was probably much less $(300,000 \mathrm{yr}$ at $10 \mathrm{~mm} / \mathrm{yr})$ than the $3 \mathrm{~m} . \mathrm{y}$. we have assumed. From available data, we cannot estimate the duration of evaporite phase in the South Atlantic any more precisely.
Leyden and co-workers have argued that because the seaward boundaries of the diapir zones on the opposing sides of South Atlantic can be matched so well, a topographically high Mid-Atlantic Ridge could not have existed when the salts were being deposited in this area (Leyden and Nunes, 1972; Leyden et al., 1976). In fact, drilling at Site 355 in the Brazil basin (PerchNielsen, Supko, et al., this volume) has suggested that in the northern South Atlantic, a Mid-Atlantic Ridge comparable to that of today in altitude, did not exist until the late Cretaceous. This conclusion has also been supported by the drilling data from Leg 3 of DSDP in the South Atlantic (Maxwell, von Herzen, et al., 1970) and by Connary (1972).

We suggest that the northern South Atlantic was in a "rift-valley stage" when the evaporites were being deposited. The central rift zone was a site of creation of the oceanic crust, at the same time the salts were filling the basin at a very rapid rate. The crust was being created in the axial zone without a high mid-ocean ridge such as in the Red Sea (Ross and Schlee, 1973) or in the Gulf of California (Larson et al., 1972; Larson, 1972). This scheme calls for "normal" sea-floor spreading since the 




Figure 10. Reconstruction of South Atlantic at the end of Aptian (modified from Leyden et al., 1976). Salt zones on both sides of the Atlantic shown by diagonal shading. AA and $C C$ refer to the segments of spreading center that must have developed just before the salt layer was split into two segments. $B B$ is a presumed spreading center under the São Paulo Plateau. Location of the profile shown as Figure $9 B$ also indicated.

beginning of opening of the South Atlantic, and does not call for any "oceanization" of pre-existing continental crust under the São Paulo Plateau as suggested by Leyden (1976). We have very little direct information on the location of this axial zone but we assume that this zone was symmetrically located with respect to the adjacent continents.

Figure 10 shows the northern and southern boundaries of the São Paulo Plateau on a reconstructed map of the South Atlantic at the end of Aptian. Because these boundaries are fracture-zone related, it is reasonable to assume that the central rift was located approximately along AA and BB in the northern South Atlantic (Figure 10). However, the split of the salt boundary took place along AA and CC (Figure 10, Leyden et al., 1976) and hence, we have to assume that the segment of the spreading center located between the two fracture zones shifted from BB to $\mathrm{CC}$ at the end of the Aptian (Figure 10). This shift has been suggested by Ponte and Asmus (1976) and is supported by the asymmetry of the present-day mid-ocean ridge with respect to the continents on either side (Leyden, 1976; Mascle and Phillips, 1972; Ladd, 1974). Furthermore, unless we accept the hypothesis of creating a transitional crust under the salt layer, without the suggested shift from BB to CC, we would have to assume that the spreading center was located along AA and CC since the initiation of rifting in the South Atlantic. This 
would require that until the end of the Aptian, the CC segment was creating oceanic crust only on its western side and that no oceanic crust was forming on its eastern side. Although Mascle and Renard (1976) suggest that the scattered seamounts along the eastern edge of São Paulo Plateau (Figure 3) may be related to fracture zones, we think that these seamounts may indicate the presumed shift of the spreading center. If a new thermal regime was created under $\mathrm{CC}$ at the end of Aptian, it initially generated unusually high amount of volcanism. After some time, the thermal regime under $\mathrm{CC}$, reverted to "normal" for mid-ocean ridges. Hence, we see the remnants of the unusually high incidence of volcanism in these seamounts. The morphology of the eastern boundary of the São Paulo Plateau suggests that sediments might be ponded on the landward sides of these seamounts, indicating that they have acted as barriers to sediments coming from the Santos Basin area. This suggests again that a high ridge was created along $\mathrm{CC}$ after the shift in the spreading center. Because the ridge created along $\mathrm{CC}$ was unusually high, the oceanic crust created at that time has remained higher than the surrounding oceanic crust and has acted as the eastern boundary for the São Paulo Plateau through time (Kumar and Gamboa, in preparation).

With the existing data we have been unable to locate the "fossil" spreading center underlying the plateau (along BB, Figure 10). If such a feature exists, it is at present buried under four or more kilometers of evaporites and sediments. Thus, at the end of Aptian, the area presently underlain by the diapirs on the two sides of the Atlantic formed a shallow platform, 500 to 1000 meters deep. It was widest in the area now occupied by the São Paulo Plateau because the entire width of the evaporite layer in this regions was then attached to the Brazilian margin. The African evaporite zone ends to the north (Pautot et al., 1973; Leyden et al., 1976) of where the fracture zone forming the northern boundary of São Paulo Plateau would intersect the African continent. The region of the plateau has subsided through time, partly through thermal subsidence and partly through sediment loading.

After the deposition of salts, a sequence consisting mainly of calcareous, hemipelagic, pelagic siliceouscalcareous, and terrigenous sediments was depositied in the northern South Atlantic. Limestones with sapropel drilled at Site 364 represent stagnant conditions that must have existed immediately after the cessation of evaporite deposition. Return of open-marine conditions is indicated by the calcareous oozes of Albian age which lie over the limestone with sapropel and which have been drilled at Sites 356 and 364 .

The conditions changed again from open-marine to restricted during the Turonian-Coniacian time. A major progradation appears to have taken place along the Brazilian margin (Ponte and Asmus, 1976). Sediments deposited on the São Paulo Plateau during this interval are black carbonaceous shales interbedded with gray nannofossil marl. The carbonaceous shales and mudstones are distal facies of coarse-grained sediments deposited contemporaneously in the Santos Basin. The mudstones and black shales drilled at Site 364 probably represent the progradation along the African margin. The progradation and stagnation in the northern South Atlantic during the Turonian-Santonian time might have resulted from a relative drop of sea level during that time. As the sea level dropped, the restriction caused by the São Paulo-Walvis ridge barrier was accentuated and prevented circulation from the south. On one hand this may explain why, although the barrier existed even in the Albian, the basin remained well oxygenated and well circulated when the relative sea level was high. On the other hand, the black shales of Sites 356 and 364 and of several sites of Leg 14 and Leg 11 of DSDP in the North Atlantic (Hayes, Pimm, et al. 1972; Hollister, Ewing, et al., 1972) might represent basin-wide oxygen-minimum conditions throughout the Atlantic during part of the upper Cretaceous.

Following the Turonian-Coniacian progradation, a transgression began in Santonian time, reducing the supply of terrigenous material to the basin; the transgression continued until the Tertiary. By Maestrichtian time, the terrigenous supply to the plateau was almost nil. On the African side, the terrigenous supply was terminated by Campanian time. The sediments deposited on the São Paulo Plateau during the Eocene time are rich in siliceous fossils and probably represent entry of cooler water into the area. Siliceous components are present in sediments of Oligocene age on the African side. Although the Miocene and younger sediments on the plateau are almost entirely pelagic, the sediments of equivalent age on the African side contain a terrigenous component. However, a Pliocene progradation did take place on the Brazilian side, but the terrigenous supply from this progradation apparently failed to reach the seaward part of São Paulo Plateau (Kumar and Gamboa, in preparation).

The foregoing discussion indicates that the Brazilian and African margins have evolved nearly identically and were affected by the same basin-wide events. The sediments on both sides vre lithologically, environmentally, and geochemically comparable. A comprehensive model for the evolution for one of the margins should therefore be generally applicable to the other.

\section{SUMMARY AND CONCLUSIONS}

During the early stages of their evolution, the continental margins off southeastern Brazil and off southern Angola experienced almost identical conditions. This is reflected in very similar lithologies, stratigraphy, and depositional environments encountered in the early parts of the geologic columns drilled at these opposing margins. The drill site off Brazil was located on the southeastern corner of São Paulo Plateau (Site 356). The drill site off Angola is located approximately $10 \mathrm{~km}$ landward of an abrupt escarpment in the outer continental margin (Site 364).

Site 356 yielded a sequence consisting of open-marine Albian limestone, Turonian-Coniacian mudstones, Coniacian-Maestrichtian marly chalks, and Cenozoic pelagic calcareous and siliceous sediments. The Albian limestone might be underlain by Aptian evaporites 
which were not penetrated. Five major reflectors, ranging in age from late Albian to Oligocene-Miocene, have been mapped across the plateau to the slope. A comparison between the stratigraphies of the São Paulo Plateau and the Santos Basin, which underlies the shelf to the west of the plateau, indicates that same major structures bound the two regions and that they have remained interconnected at least since the late Cretaceous.

Geophysical data indicate that the São Paulo Plateau is underlain by 1 to $2 \mathrm{~km}$ of terrigenous and calcareous sediments which overlie 2 to $3 \mathrm{~km}$ of Aptian evaporites. The São Paulo ridge, located at the southern edge of the plateau, is an expression of a fracture zone which bounds the plateau to the south. Another fracture zone appears to form the northern boundary of the plateau. Although this fracture zone does not have a morphologic expression such as a ridge, it offsets magnetic anomalies to the east of the plateau and appears to connect with east-west trending faults mapped on the continental shelf and in inland areas.

Site 364 yielded Aptian-Albian limestones with sapropels, Albian linestones and Turonian-Santonian mudstones with sapropels, followed by chalks and oozes. The oldest unit at this site appears to lie directly over an evaporitic sequence. The Albian limestones on the opposing sides of the Atlantic are very similar. The overlying mudstones at the two sites are lithologically and geochemically almost identical. Two of the oldest reflectors mapped under the São Paulo Plateau match in age, lithology, and subbottom depths with reflectors drilled and dated at Site 364 .

On the basis of available data, we propose the following reconstruction of the early history of northern South Atlantic. As the opening began in the Neocomian, coarse clastics were deposited in coastal basins on both sides of the Atlantic. During Aptian time, evaporites which at least in part overlie oceanic crust, were deposited. The Walvis Ridge and the São Paulo ridge formed a continuous barrier at the southern end of this evaporite basin. Parts of the barrier were initially at, or above sea level. At the end of the Aptian, a segment of the initial spreading center, which was located between the fracture zones that bound the São Paulo Plateau, shifted to the east. Following this shift, the salt layer which was originally continuous across the ocean, was split along the present-day seaward boundaries of the two diapir zones located on either side of the northern South Atlantic. Stagnant conditions prevailed in the basin at the end of the evaporite deposition, but it became well oxygenated during Albian time. Another period of stagnation followed during the TuronianConiacian time. The waters of the South Atlantic have remained well circulated and well oxygenated since then.

\section{ACKNOWLEDGMENTS}

Financial support for this work was provided by the National Science Foundation through the office for the International Decade of Ocean Exploration under Grant NSFIDO-72-06426 and through the Division of Environmental Sciences under Grants GA 27281 and DES71-00214A08, by the Office of Naval Research by Contract N00014-75-C-0210.
Financial support for L.A.P. Gambôa was from Coordenação do Aperfeiçoamento de Pessoal de Nivel Superior (CAPES), and Conselho Nacional de Desenvolvimento Científico e Tecnológico (CNPq), Brazil. This paper is a result of the cooperative L-DGO-REMAC study of the continental margin of Brazil. J. Mascle was supported by C.N.R.S., and the Geobrasil cruise was funded by CNEXO-COB.

H.E. Asmus of Petrobrás, James Forseman of Phillips Petroleum, and M.A. Gorini, G.M. Bryan, R. Leyden, J.E. Damuth, and A. Watts of L-DGO have discussed with us the various problems mentioned in this paper and have provided helpful suggestions. James Foresman has also provided geochemical measurements on the black shales. We thank W.B.F. Ryan and R. Houtz for reading the manuscript and providing suggestions for its improvement. Technical assistance was provided by B. Hautau and V. Gorini.

\section{REFERENCES}

Asmus, H.E., 1975. Controle estrutural da deposição Mesozóica nas bacias da Margem Continental Brasileira: Rev. Brasileira Geociências: v. 5, p. 160-175.

Asmus, H.E. and Ponte, F.C., 1973. The Brazilian marginal basins. In Nairn, A.E.M. and Stehli, F.G. (Eds.), The Oceans basins and margins, v. 1, The South Atlantic: New York (Plenum Press), p. 87-133.

Baccar, M.A., 1970, Evidencias geofisicas do pacote sedimentar no Plateau de São Paulo: 24th Brazilian Geol. Congr. Trans., p. 201-210.

Beck, R.H. and Lehner, P., 1974. Oceans: new frontier in exploration: Am. Assoc. Petrol. Geol. Bull., v. 58, p. 376395.

Bolli, H.M., Ryan, W.B.F., et al., 1975. Basins and margins of the eastern South Atlantic: Geotimes, v. 20, p. 22-24. in press. Initial Reports of the Deep Sea Drilling Project: Volume 40: Washington (U.S. Government Printing Office).

Brink, A.H., 1974. Petroleum geology of Gabon basin: Am. Assoc. Petrol. Geol. Bull., v. 58, p. 216-235.

Bullard, E.C., Everett, J.E., and Smith, A.F., 1965. The fit of the continents around the Atlantic. In Blackett, P.M.S., Bullard, E., and Runcorn, S.K. (Eds.), A symposium on continental drift: Phil. Trans. Roy. Soc. London, Ser. A, v. 258, p. $41-51$.

Butler, L.W., 1970. Shallow structure of the continental margin, southern Brazil and Uruguay: Geol. Soc. Am. Bull., v. 81, p. 1079-1096.

Campos, C.W., Ponte, F.C., and Miura, K., 1974. Geology of the Brazilian Continental Margin. In Burk, C.A. and Drake, C.L. (Eds.), Geology of continental margins: New York (Springer-Verlag), p. 447-462.

Connary, S.D., 1972. Investigations of the Walvis Ridge and environs: Ph.D. Thesis, Columbia University, New York, 228 p.

Delteil, J.R., Valery, P., Motadert, L., Fondeur, C., Patrait, P., and Mascle, J.R., 1974. Continental margin in the northern part of the Gulf of Guinea. In Burk, C.A. and Drake, C.L. (Eds.), Geology of continental margins: New York (Springer-Verlag), p. 297-311.

Emery, K.O., Uchupi, E., Phillips, J., Bowin, C., and Mascle, J., 1975. Continental margin off western Africa: Angola to Sierra Leone: Am. Assoc. Petrol. Geol. Bull., v. 59, p. 2209-2265.

Faure, H., 1976. Vertical evolution of continental margins: In Proc. Internat. symposium on continental margins of Atlantic type, São Paulo, Brazil, Oct. 13-17, 1975: Anais da Academia Brasileira de Ciências, v. 48, Supplement, p. 81-87. 
Foresman, J.B., in press. Organic geochemistry: DSDP Leg 40, continental rise of southwest Africa. In Bolli, H.M., Ryan, W.B.F., et al., Initial Reports of the Deep Sea Drilling Project, Volume 40: Washington (U.S. Government Printing Office).

Francheteau, J. and Le Pichon, X., 1972. Marginal fracture zones as structural framework of continental margins in South Atlantic Ocean: Am. Assoc. Petrol. Geol. Bull., v. 56, p. 991-1007.

Fulfaro, V.J., 1975. The Southern Brazilian coast evolution and the associated tectonic sedimentary framework. In Abstracts, Internat. symposium on continental margins of Atlantic type, São Paulo, Brazil, Oct. 13-17, 1975, p. I-7.

Geological Map of Brazil, 1971. Ministry of Mines and Energy, National Department of Mineral Production, Rio de Janeiro, Brazil.

Gorini, M.A. and Bryan, G.M., 1976. The tectonic fabric of the Equatorial Atlantic and adjoining continental margins: Gulf of Guinea to northeastern Brazil. In Proc., Internat. symposium on continental margins of Atlantic type, São Paulo, Brazil, Oct. 13-17, 1975: Anais da Academia Brasileira de Ciências, v. 48, Supplement, p. 101-119.

Hayes, D.E., Pimm, A.C., et al., 1972. Initial Reports of the Deep Sea Drilling Project, Volume 14: Washington (U.S. Government Printing Office).

Hollister, C.D., Ewing, J.I., et al., 1972. Initial Reports of the Deep Sea Drilling Project, Volume 11: Washington (U.S. Government Printing Office).

Ladd, J.W., 1974. South Atlantic sea floor spreading and Caribbean tectonics: Ph.D. Thesis, Columbia University, New York. , 200 p.

Larson, P.A., Mudie, J.D., and Larson, R.L., 1972. Magnetic anomalies and fracture-zone trends in the Gulf of California: Geol. Soc. Am. Bull., v. 83, p. 3361-3368.

Larson, R.L., 1972. Bathymetry, magnetic anomalies, and plate tectonic history of the mouth of the Gulf of California: Geol. Soc. Am. Bull., v. 83, p. 3345-3360.

Larson, R.L. and Ladd, J.W., 1973. Evidence for the opening of the South Atlantic in the Early Cretaceous: Nature, v. 246 , p. $209-212$.

Le Pichon, X. and Hayes, D.E., 1971. Marginal offsets, fracture zones, and the early opening of the South Atlantic: J. Geophys. Res., v. 76, p. 6283-6293.

Leyden, R., 1976. Salt distribution and crustal models for the eastesrn Brazilian margin. In Proc. Internat. symposium on continental margins of Atlantic type, São Paulo, Brazil, Oct. 13-17, 1975: Anais da Academia Brasileira de Ciências, v. 48, Supplement, p. 159-168

Leyden, R., Asmus, H., Zembruscki, S., and Bryan, G., 1976. South Atlantic diapiric structures: Am. Assoc. Petrol. Geol. Bull., v. 60, p. 196-212.

Leyden, R. and Nunes, J.R., 1972. Diapiric structures offshore southern Brazil: 24th Brazilian Geol. Congr. Trans., p. $45-50$.
Leyden, R., Bryan, G., and Ewing, M., 1972. Geophysical investigations on African shelf: 2. Margin sediments form Gulf of Guinea to Walvis Ridge: Am. Assoc. Petrol. Geol. Bull., v. 56, p. 682-693.

Leyden, R., Ludwig, W.J., and Ewing, M., 1971. Structure of continental margin off Punta del Este, Uruguay, and Rio de Janeiro, Brazil: Am. Assoc. Petrol. Geol. Bull., v. 55, p. $2161-2173$.

Marsh, J.R., 1973. Relationship between transform directions and alkaline igneous rocks lineaments in Africa and South America: Earth Planet. Sci. Lett., v. 18, p. 317-323.

Mascle, J.R., 1975. Geologie sous-marine du Golfe de Guinea: Doct. Sci. Thesis, Univ. Paris, 385 p.

Mascle, J.R., and Phillips, J.D., 1972. Magnetic smooth zones in the South Atlantic: Nature, v. 240 , p. $80-84$.

Mascle, J.R. and Renard, V., 1976. The marginal São Paulo Plateau, comparison with the southern Angolan Margin. In Proc., Internat. symposium on continental margins of Atlantic type, São Paulo, Brazil, Oct. 13-17, 1975: Anais da Academia Brasileira de Ciências, v. 48, Supplement, p. 179-190.

Mascle, J.R. and Sibuet, J.C., 1974, New pole for early opening of South Atlantic: Nature, v. 252, p. 464-465.

Maxwell, A.E., von Herzen, R., et al, 1970. Initial Reports of the Deep Sea Drilling Project, Volume 3: Washington (U.S. Government Printing Office). p.

Pautot, G., Renard, V., Daniel, J., and Dupont, J., 1973. Morphology, limits, origin, and age of salt layer along South Atlantic African margin: Am. Assoc. Petrol. Geol. Bull., v. 57, p. 1658-1672.

Perch-Nielsen, K., Supko, P.R., et al., 1975. Leg 39 examines facies changes in South Atlantic: Geotimes, v. 20, p. 2628.

Ponte, F.C., and Asmus, H.E., 1976. The Brazilian marginal basins: Current state of knowledge. In Proc. Internat. symposium on continental margins of Atlantic type, São Paulo, Brazil, Oct. 13-17, 1975: Anais da Academia Brasileira de Ciências, v. 48, Supplement, p. 215-329.

Renard, V. and Mascle, J., 1974. Eastern Atlantic continental margins: various structures and morphological types. In Burk, C.A. and Drake, C.L. (Eds.), The geology of continental margins: New York (Springer-Verlag), p. 285292.

Reyment, R.A. and Tait, E.A., 1972. Biostratigraphical dating of the early history of the South Atlantic Ocean: Phil. Trans. Roy. Soc., London, Series B, v. 264, p. 55-95.

Rideg, P., 1974. Ubatuba lineament: identification of new pre-drift feature: Am. Assoc. Petrol. Geol. Bull., v. 58, p. 2362-2366.

Ross, D.A. and Schlee, J., 1973. Shallow structure and geologic development of the southern Red Sea: Geol. Soc. Am. Bull., v. 84 , p. $3827-3848$. 